\title{
高速引張試験用荷重計の試作
}

\author{
帝人 侏 $千$ 布正雄(会員)
}

\section{Load Cell for High-Speed Tensile Testing of Yarns}

Masao Chifu

Fiber and Textile Research Institute, Teiiin Limited, Ibaragi, Osaka-fu

\begin{abstract}
A high-frequency, responsive-force gauge is nedeed to observe the actual stress-strain curve of a filament yarn in an extreme short loading time ranging in ms during high-speed testing.

A standstill indication must be formed with the D. C out-put brom the force-gauge, fecause dead loads are charged to calibrate the gauge with weights.

The gauge of a yarn-measuring instrument must have temperature stability and zero-level stability.

We have designed and built a high frequency responsive force gauge with which to investigate the behavior of a filament yarn. The gauge is based on the princtple that the frequency of a zero temperature coefficient (A.T cut)quartz crystal resonator of radio frequency shibts under external pressure.

The characteristics of the quartz crystal resonator borce gauge show that the frequency response is from D.C to about $6 \sim 7 \mathrm{KHz}$ and stable.

Further work is in progress to improve the mechanism of the force gauge so as to obtain a higher response.

(Received May 29, 1969)

摘 要

目 的絨維測定用, 高速引張り試験に扣ける荷重計の開発を試みた.

数 $\mathrm{ms}$ という短い時間に扣ける荷重の変化を測定するために快，数 $\mathrm{KHz} \sim 10 \mathrm{KHz}$ に及ぶ高い周波数特性か要求される。一力，標準 分銅で目盛りの較正を行なうときには指示を静止させるために直流出力が必要となる.

このほかに繊維計測の面からも温度安定性の良いことなどの要件があり，従来の荷重検出力法では一長一短であった。そこで零温度 係数水晶発振子(A.T.カット)の発振周波数が外力で変化することを利用して, これらの要件を満たす荷重計の開発を試みた。

結 果 周波数灾答は直流成分から約 $6 \sim 7 \mathrm{KHz}$ に及び, 初期ドリフト，温度ドリフト，共に安定な特性を得た.

$10 \mathrm{KHz}$ をこえる灾答周波数特性を得るためには，荷重部の機構に今後の検討が必要である.
\end{abstract}

（昭和 44 年 5 月 29 日 受理）

\section{1. 緒言}

繊維の性質を知る主要な試験方法の一つに，引張り強 さの測定がある，その試験は纎維が切れるまで静かに引 張ったときの弓張り強さと，そのゆがみの関係を表わす 荷重一伸張曲線である. この場合の引張り速度は早くて も $1 \mathrm{~m} / \mathrm{min}$ にすぎないため, 一般に静的試験と言われ ている.

自動車用タイヤの高速度下で起きる破壊現象はタイヤ コードの静的試験から予測することは困難で, たとえば 高速度衝撃試験が実車走行試験と良い相関を示すと報告

$$
\text { されている. }
$$

合成繊維のような高分子材料は力学的緩和時間の分布 が厇く，かつ大変形での挙動は複雑である。そうした場 合高速変形での挙動は静的変形と違ったものが考えら れ，静的な変形から高速度下の変形を予測することは困 難である.

したがって，高速度で繊維を引張り，その場合の繊維 の受ける引張り力を測定するのがより実用に即した試験 方法と考えられる. これが高速引張り試験であり, 静的 試験に対して動的試験と呼ばれている.

引張り速度が早くなると測定にいろいろな困難が伴っ 
てくるますず繊維に加えられる力を測定する荷重計の応 答速度の早いこと, 高速度で運動しながら穢維をつかん で弓張るチャックの構造, あるいは引張り機構, 引張り 速度や変位の記録装置などいずれも低速度の引張り試験 機には現われなかった問題が起ってくる．本研究ではま ずその内の一つである荷重計の開発を試みた。

いま試料の長さを $30 \mathrm{~cm}$ としたときに，これに力を加 えてゆがみを与え，切断するときの伸びが $20 \%$ とする 之, $6 \mathrm{~cm}$ の変形で切断するととになる. との場合 $10 \mathrm{~m} /$ sec の弓張り速度では荷重計が力を受けている時 間は $6 \mathrm{~ms}$ である.

荷重の变化する速さと，荷重計及びそれに接続してい る増巾器の応答周波数の関係についてはすでに多くの研 究が行なわれており $6 \mathrm{~ms}$ の間に終わってしまう現象を 測定するためには測定系の応答周波数は $10 \mathrm{KHz}$ あれば 良いと言われている。

一方, 次の理由によって直流出力が取り出せる必要が ある．測定装置の検量線を求めるには荷重計に標準分銅 を掛けたときのブラウン管上の目盛りの移動によって行 なわれる，乙のとき，静荷重を与えている間，目盛りが 静止していなければならない。つまりとのときの荷重計 の忘答周波数は $0 \mathrm{~Hz}$ (直流出力) であることが要求され る.

あちろん, この荷重計に接続される增㠲器にあ広い周 波数带域を持った直流増巾器が使われる. また，検出感 度む,強度の小さい未延伸系の測定の場合を考えれば, 才 シロ スコープのブラウン管上でフルスケール200〜300 $\mathrm{gr}$ 前後の感度が要求される。

繊維用の弓張り試験は，目的によっては，しばしば $100 \sim 200^{\circ} \mathrm{C}$ の高温度で行なわれる場合がある。繊維を 荷重計に取り付けて加熱炬に釣下げたとき，加熱炉から の上昇気流の一部が荷重計にふれるため, 温度安定性が 悪いと，オシロ スコープの0 点が動摇する。しかす繊 維を加熱炬の中に入れたまま 0 点が安定するまで放置す ることはゆるされないため, 温度安定性が悪いと操作が きわめて困難になる。

以上のことから検出部に必要な特性をまとめ机ば,

(1) $0 \mathrm{~Hz} \sim 10 \mathrm{KHz}$ の応答性を持つこと.

(2) フルスケール200〜300 gr の測定がなされるとと.

(3) 温度安定性の良いこ之。

の要求されるととが了解されよう.

上記の要求特性から市販の荷重計について考えてみ る.

（1）ワイヤーストレインゲージはきわめて高精度, かつ高感度のものが得られているが，応答周波数の限度 が1〜 $2 \mathrm{KHz}$ 前後で, 高速変形の測定には適しない.

(2) 半導体ストレン ゲージはワイヤーストレンゲー
ジよりも感度が高いため, 応答周波数の高いものの製作 あできるが，温度による影響を受けやすい，温度補償の 方法むかなり研究されているが実際に市場で所要の特性 を持つ半導体を入手することは困難である.

（3）応答の早い荷重計に水晶あるいは特殊なセラミッ クのピエゾ効果を応用したあのがある. チャージ増巾器 を接続すれば $0.1 \mathrm{~Hz} \sim 100 \mathrm{KHz}$ というきわめて広い範 囲の周波数にわたって測定することができて，しかも $1 \mathrm{~V} / 10 \mathrm{gr}$ と感度の高いあのあある. しかし $\mathrm{OHz}$ に近 い応答を要求する場合に $0.1 \mathrm{~Hz}$ よりあさらに低い周波 数まで拡張できるが， 0 点安定性が著しく悪化する欠点 がある.また，乙の形式の荷重計は引張り方向のみなら ず，他の方向，たとえば引張り軸に垂直な方向の出力が 意外に大きいため, 引張り機構などから不測の振動が混 入して悩まされる場合が多い.

このように高速引張り試験用荷重計として容易に入手 し得るあのはそれぞれ一長一短あるのが現状である.

\section{2. 実 験 装 置}

通信用水晶発振子に力を与えると, 発振周波数がわず かに変化することは1951年来知られている. E. A. Gerber はこの現象を利用してバイメタルで周囲温度の变化 に灾じて水晶発振子に加わる力を変化させて, 発振周波 数の温度ドリフトを補償する装置を考案した。本研究は 水晶発振子の温度安定性の良いおよび周波数変調方式に は， $\mathrm{OHz}$ までの応答性があるととを利用したあのであ る.

第 1 困は，水晶発振子に力を与えて発振周波数の偏移

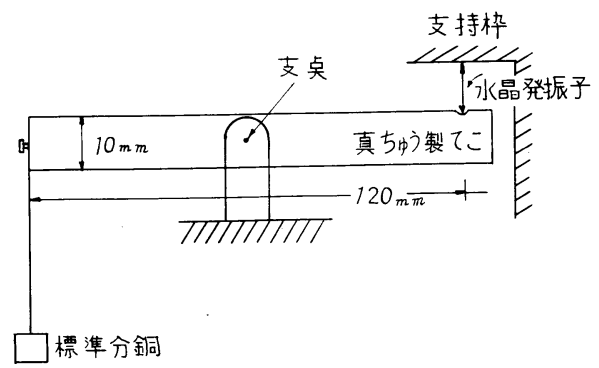

第 1 図 静荷重特性測定実験装置

を測定する装置を示したもので，乙の研究の予備的実験 である。

水晶発振子に直接引張り荷重を加えることは構造上困 難であるから，ててを用いて圧縮荷重として加える。て この長さは約 $12 \mathrm{~cm}$ でその中央をピンで支えてある。一 端に釣下げられた標準分銅によって加えられた荷重は他 端に挾まれて固定された水晶発振子に与えられる. 実験 亿使用した水晶発振子は発振周波数 $5 \mathrm{MHz}$ の A.T. 力 ットである。

第 2 図に外観の例を示す。 


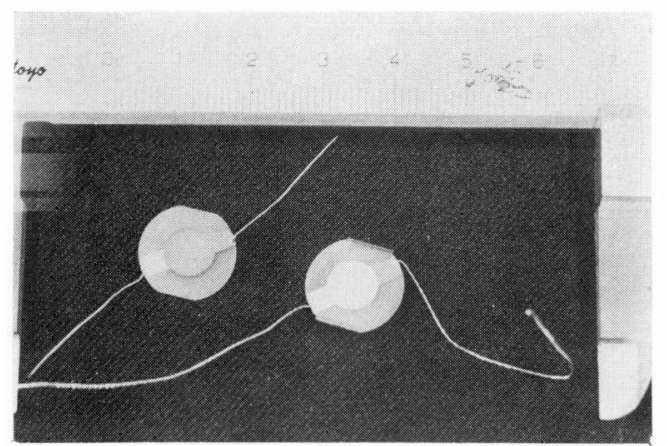

左上が水晶発振子素子で右下はこれに 保護金具を装着したものである。金具 は 2 号〜 4 号注射針を半円形に削り

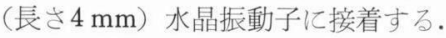

第 2 図荷重検出用水晶発振素子

直径約 $14 \mathrm{~mm}$, 厚さ約 $0.33 \mathrm{~mm}$ の薄い円板状で, その 両面には電極が金鍍金されており，縁に近い部分に一対 の細いリード線を取り付けて発振回路に接続される。発 振回路は第 3 図に示されるようにトランジスタ 3 個から なる簡単な無調整発振回路である.

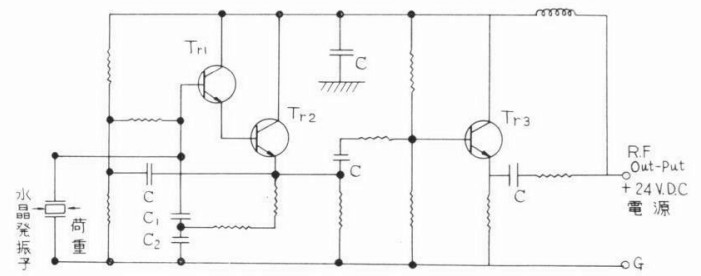
$\mathrm{T}_{\mathrm{r} 1}, \mathrm{~T}_{\mathrm{r} 2}, \mathrm{~T}_{\mathrm{r} 3}: 2 \mathrm{SC} 289$
$\mathrm{C}_{1} \quad: 200 \mathrm{pf}$
$\mathrm{C}_{2} \quad: 100 \mathrm{pf}$
$\mathrm{C}_{3} \quad: 1000 \mathrm{pf}$

第3図発振回路

水晶発振子はすでに述べたように薄い円板であるか ら，これに直接引張り荷重を与えるのはむずかしいので 圧縮荷重の形で力を加える. 力を与える力向は円板の直 径方向である.（(注）水晶発振子の表面（平面）飞垂直 方向に力を与えると発振状態にき加めて敏感に影響が現 わ机、たとえばわずかな塺の付着，あるいは油類によ る污染も発振周波数が変動し, もし污染が著しい場合に は発振が停止する。取り扱いに際しては平面にさわらな いように注意するととが必要である)

冈板の縁加ら直径方向に力を与える位置は円周上 $180^{\circ}$ に涉って考えられる。いま力を加える方向の基準として 水晶発振子の $X$ 軸を取り, 乙の $X$ 軸上力を加える力向上 のなす角度を $\alpha$ とする。(水晶の結晶軸 $(X, Y, Z)$ は 原石加ら発振子老裁り出す際に $X$ 線解析によって決定さ れるものであって，本実験に使用した水晶発振子にはそ

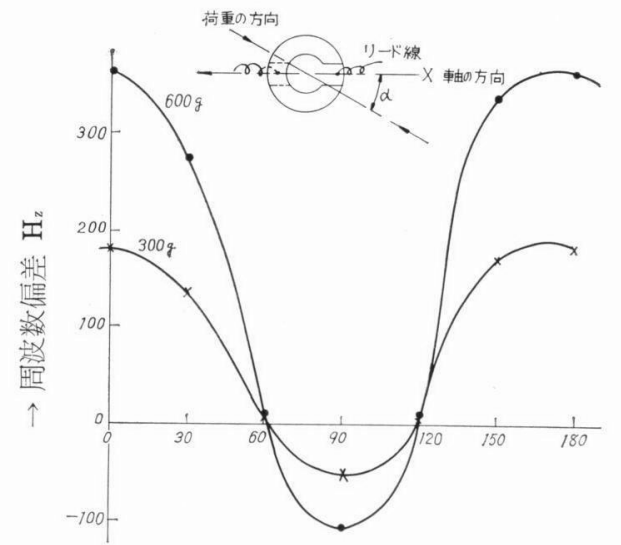

$\rightarrow \mathrm{X}$ 軸方向とのなす角 $\alpha$ 基本周波数 : $5 \mathrm{MH}_{z}$

第 4 図 周波数偏位と荷重方向

の面上に $X$ 軸の方向が表示されている).第 4 眓は力在加 元る方向上 $X$ 軸之のなす角度を变化させた場合に，一定 荷重(300 gr 书よび $600 \mathrm{gr})$ における周波数の変化する状 況を示したものである. $X$ 軸に沿って力を与えた場合, 力の変化（300 g-600 g) に応ずる周波数変化が最大上な る.したがってとの角度が最大感度の位置である.

第 5 図は最大感度の位置における水晶発振子に加える

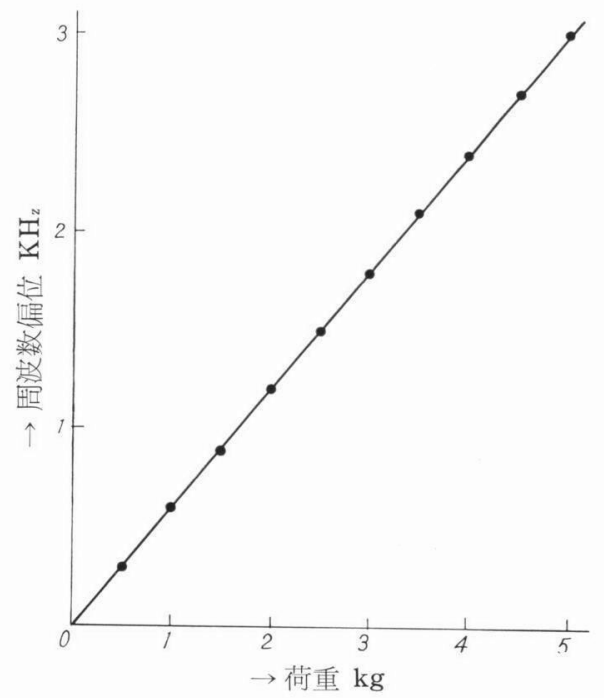

第 5 図 最高感度の位置における周波数偏位と荷重

カの大きさと周波数変化の関係走示したものであって, 約 $5 \mathrm{~kg}$ まで荷重に対して周波数変化は直線的に約 $3 \mathrm{~K}$ $\mathrm{Hz}$ 増加している. $5 \mathrm{~kg}$ 以上の荷重では発振周波数が不 安定之なるが荷重を軽減すれば再び安定な発振状態に回 復した。 


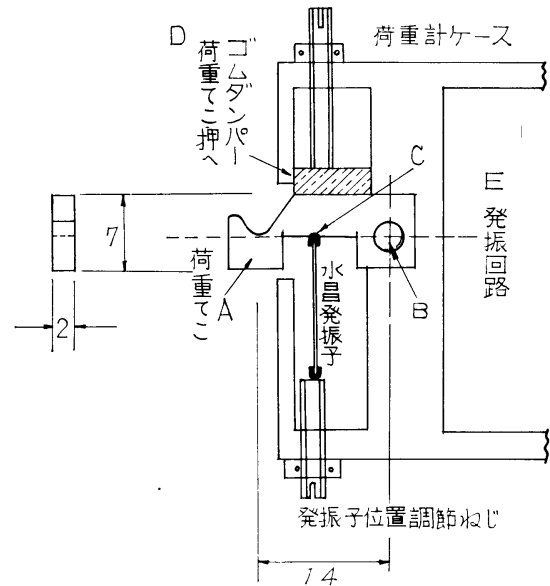

$\mathrm{A}$ ：水晶発振子荷重用てこで $\mathrm{A}$ 点に糸を引掛ける.

B : 支点

$\mathrm{C} ：$ 水晶発振子および保護金具

$\mathrm{D}$ : ゴムタンパーは糸が切断し, 荷重がなくなった ときにてこの振動を㧕制するむのである。

$\mathrm{E}$ : 荷重計ケース内に発振回路プリント板が取り付 けられる。

第 6 図高速弓張り試験用荷重計詳細図

第 6 図は実際に高速引張り試験に用いた荷重検出部の 構造を示したものである．糸に加えられた引張り荷重は 静荷重測定之同じ要領でてとで約 2 倍の大きさに拡大さ れて, 水晶発振子に加えられる.

てこはこの部分の機械的共振周波数の低下を防ぐた め, ヤング率の比較的高い金属，(工具鋼，(KS-5)）に 熱処理をほどこしたもので, 形状も許す限り小型に設計 した. 系張力の加わる部分 $\mathrm{A}$ 上, 支点 $\mathrm{B}$ および水晶発振 子に接している部分 $\mathrm{C}$ は，同一線上に来るようにし，簡

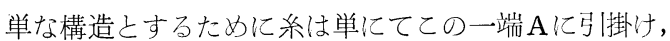
あるいは巻き付け得るようにしてある.

\section{3. 周波数弁別回路}

前述のように発生信号は荷重によって変化する周波数 変調波であり, その無荷重時の発振周波数は約 $5 \mathrm{MHz}$ である。

第 7 図は，周波数弁別回路のブロック図である. 入力 信号は 2 段の周波数変換回路で $200 \mathrm{KHz}$ に変換される.

第 2 段目の周波数变換用局部発振器は, $100 \mathrm{KHz} \sim 150$ $\mathrm{KHz}$ の可変発振回路になっている. 水晶発振子の製造 時バラツキわ ${ }_{+0}^{-40} \mathrm{KHz}$ を微調整するためのものである. この周波数变換回路で中心周波数が正確に $200 \mathrm{KHz}$ に なった信号は周波数弁別回路に導かれる. 周波数弁別回 路は直線性の良い2 同調回路方式である.

第 8 図は周波数弁別回路の出力特性を示したもので， 周波数弁別出力は第 9 図に示されるような特性の $20 \mathrm{~K}$ $\mathrm{Hz}$ の低域炉波器により, $200 \mathrm{KHz}$ の成分の除去を行な

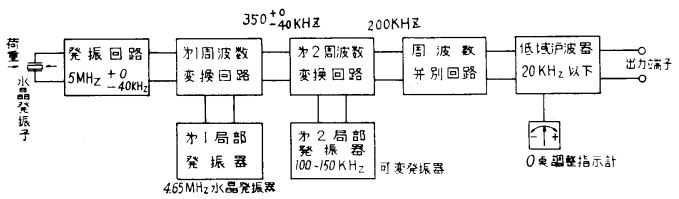

1. 第 2 局部発振器は約 $50 \mathrm{KHz}$ 可変できる安定な 発振回路が必要. 屯し不安定であると出力が変 動する.

2. 周波数弁別回路と低域沪波器との間には直流増 幅器（エミッタホロアーまたはソースホロアー 回路）を一段入れ，両者のインピーダンスを調 整する.

3. 各段間の高周波部分のしゃへいを注意して行な わないと, 出力波形が乱れる.

第 7 図 荷重検出部ブロック网

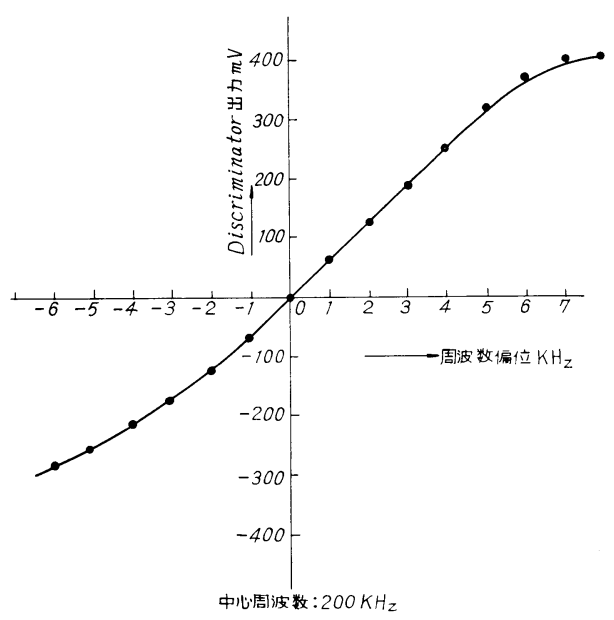

第 8 図 周波数弁別回路の出力特性

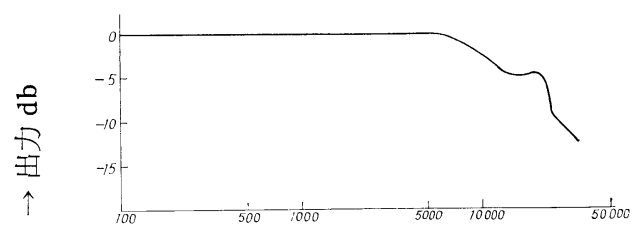

$\rightarrow$ 周波数 $\mathrm{H}_{2}$

周波数弁別回路の不平衡のため $200 \mathrm{KH}_{\mathrm{z}}$ の 信号がわずかに現われる (carrier leak). これを十分に除かないと，出力波形に重塁 して画像が太くなる.

第 9 図 周波数弁別回路に持続された低域部波特性

いオシロ スコープの垂直軸に接続される.

第10図は，乙の周波数弁別回路を用いた荷重一出力の 関係を示すものである. 水晶発振子に約 $5 \mathrm{kgr}$ の荷重を 与えたときの直流出力は約 $200 \mathrm{mV}$ であった.

第11図は電源投入時における初期変動を示したもので 


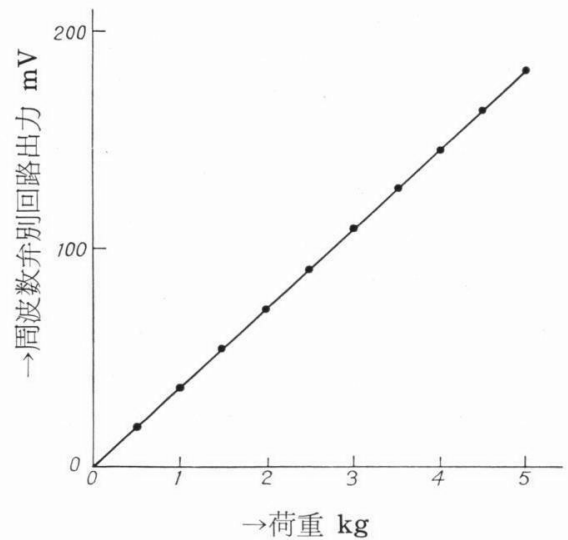

第10図 荷重計の総合静特性

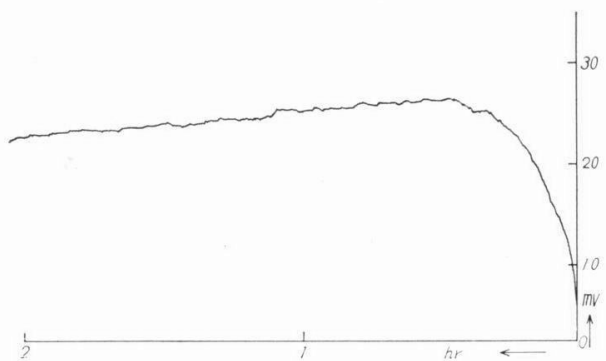

荷重計は無荷重, 電源を入机てから

約 30〜60 min に約 $25 \mathrm{mV}$ 移動し,

その後は比較的安点に推移する. 主之

して最終段の直流増幅回路，および第

2 局部発振器の変動であろう.

第 11 図電源投入時の初期変動

ある. 水晶発振子に加える荷重が 0 のとき約 $30 \mathrm{~min} \sim 1$ hr に約 $25 \mathrm{mV}$ の変動が認められる. これは最大荷重 $5 \mathrm{~kg}$ 負荷時の出力 $200 \mathrm{mV}$ の約 $12.5 \%$ に相当するが，そ れ以降はきわめて安定に推移することを示している.

第12図はこの装置に $625 \mathrm{gr}$ の荷重在 $1 \mathrm{~min}$ 約 5 回の

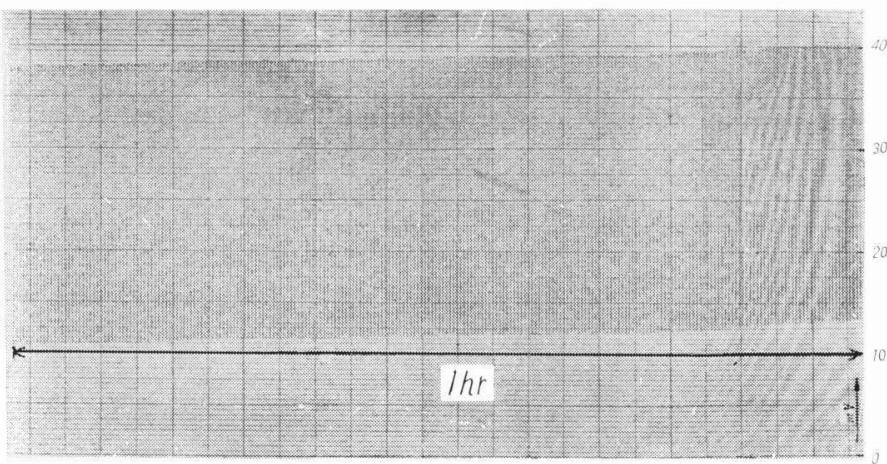

繰り返し荷重を与えたときの荷重計の出力の再現性およ び 0 点のドリフトを示す. $625 \mathrm{~g}$ の荷重により約 $28 \mathrm{mV}$ の出力示し, $1 \mathrm{hr}$ で約 $4 \mathrm{mV}$ の 0 点移動が認められる. 第12図 荷重計の再現性および動作点の安定性
割合で静かに繰り返し加えたときの出力の変動を示した あのであって, 再現性および基線の変動など使用目的の 時間内では十分なほど安定していると言える.

\section{4. 引張 り機構}

本研究における弓張り機構は荷重計の性能試験を目的 としたものであるから, ストローク約 $50 \mathrm{~cm}$, 引張り速 度約 $10 \mathrm{~m} / \mathrm{sec}$ 前後の性能を得られるだけにとよ゙め, で きるだけ簡単な構造を採用した。したがって繊維引張り 試験機としての必要な性能をすべて期待したものではな ().

引張り機構は, 压空でピストンを押し下げる形式であ って, シリンダー直径 $30 \mathrm{~mm}$ ，ストローク $70 \mathrm{~cm}$, 空 気压 $0 \sim 5 \mathrm{~kg} / \mathrm{cm}^{2}$ である. ただし窒素ボンべを使用す れば 0 〜 $20 \mathrm{~kg} / \mathrm{cm}^{2}$ となる(13図)，引張り速度の調節は 空気圧を調節して行なった。

この引張り試験機に繊維を取りつけて荷重計の性能を 調心るに先立って，あらかじめ引張り速度の検定を行な った，その办法はチャックに全長 $2 \mathrm{~m}$ 位の録音テープの

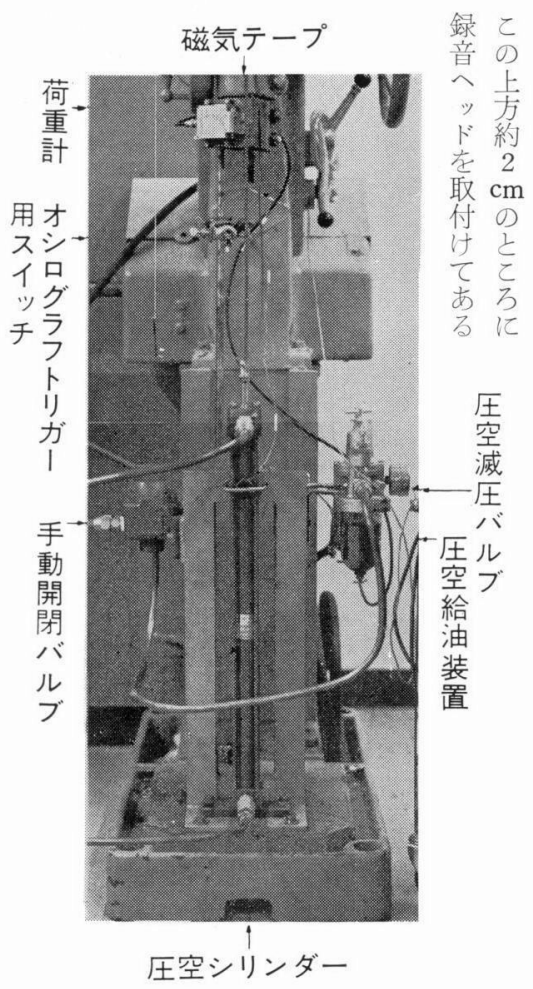

圧空シリンダーは約 $5 \mathrm{~kg} / \mathrm{cm}^{2} の$ 圧 空配管に接続され，減圧バルブで調 節する。振動在除くため, 重量約 $1 \mathrm{t}$ （工作機械のフレームを改造）の鋳 鉄製架台に取付けてある。

第13図 压空式高速弓張り機構 


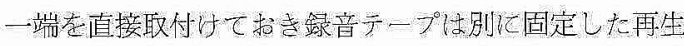

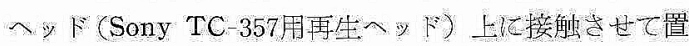

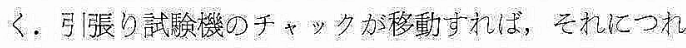

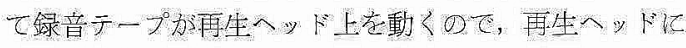
録音出力汃得られる。

録音テープには録音器で $19 \mathrm{~cm} / \mathrm{sec} の$ す速さで $190 \mathrm{~Hz}$

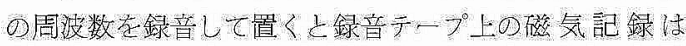

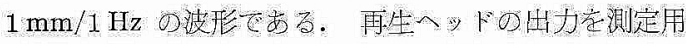
オシロダラフル接続すれば録音テープ务 $1 \mathrm{~mm}$ 移動す 要次 $1 \mathrm{~Hz}$ の波形か観誢さ机る.

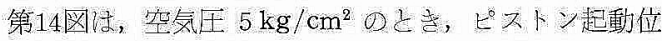

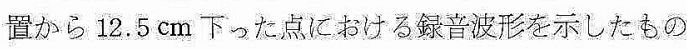
であ. $1 \mathrm{~ms}$ 的間に約 $7.5 \mathrm{~mm}$ テープか移動している. したがって，この点し叔もピストン速度は約 $7.5 \mathrm{~m} /$ $\mathrm{sec}$ で發. (第14図, 横軸 $100 \mathrm{us} / \mathrm{cm}$, 縦軸 $0.1 \mathrm{v} / \mathrm{cm}$ ) このようにして $2.5 \mathrm{~cm}$ でよにピストン速度定求め， プ

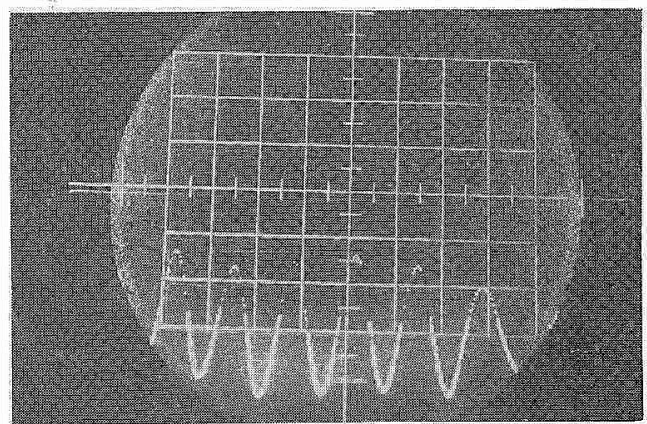

横軸 : $100 \mu \mathrm{s} / \mathrm{cm}$ 縦軸 $: 0.2 \mathrm{~V} / \mathrm{cm}$,

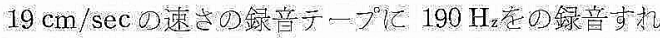

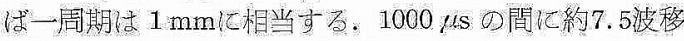

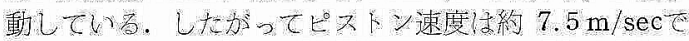
毒.

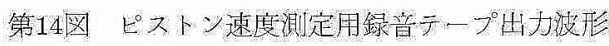

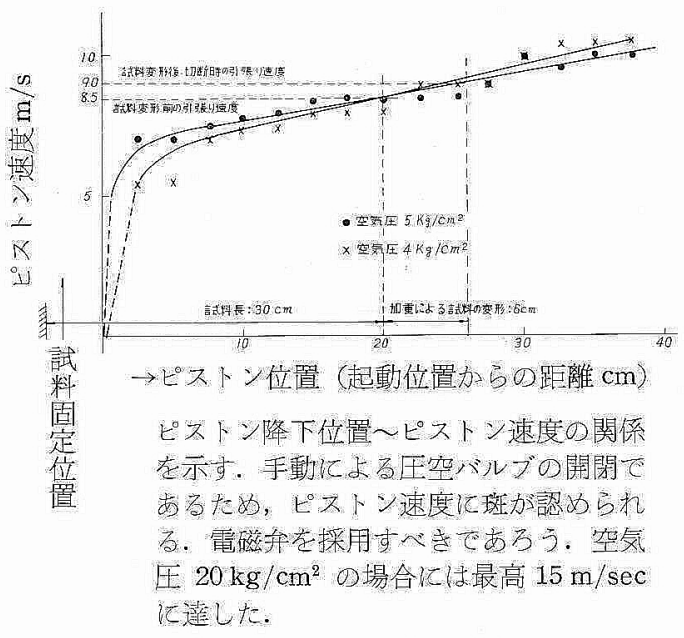

第15図 ピストソ走行速度
ロットしたのか第15図である・ピストン部分の慣性によ 过起動位置办らの立上りは比較的良好であるか，ピス卜 ンの知動を共に，觔时速度は上昇している。

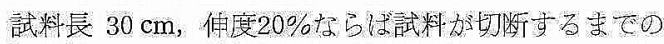

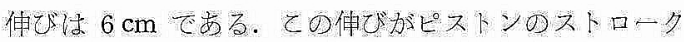

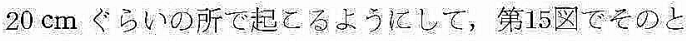
きのピス卜速度を求好る。ピストンが $20 \mathrm{~cm}$ 下った 位置では約 $8.5 \mathrm{~m} / \mathrm{sec}, 26 \mathrm{~cm}$ 0点で $9 \mathrm{~m} / \mathrm{sec}$ である.

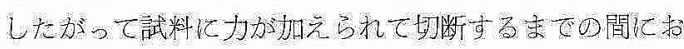

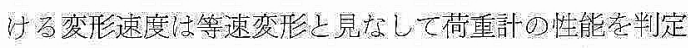

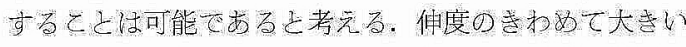

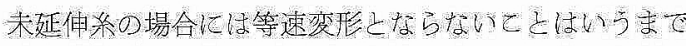

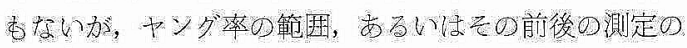

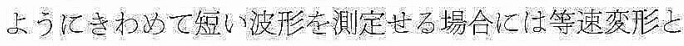
見な世施方。

\section{5. 動 特 性}

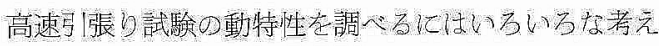

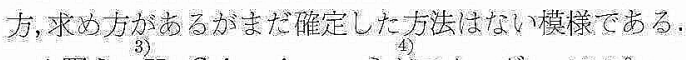

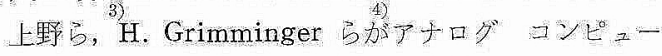

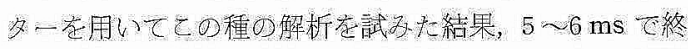

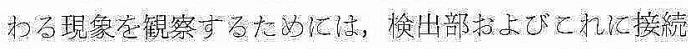

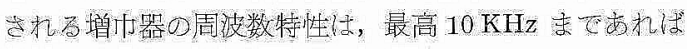
理想飞近い之述へている.

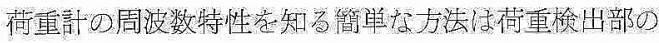

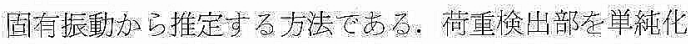

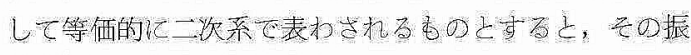

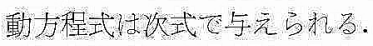

$$
m \ddot{x}+\eta \dot{x}+G x=F(t)
$$

हce

$$
\begin{aligned}
& m \text { : 振勒䒺@有效質量 } \\
& \eta \text { : 粘性系数 } \\
& G \text { : バ祦数 } \\
& F(t) \text { : 外力 }
\end{aligned}
$$

外力 $F(t)=0$ 之置いた式の蟹の自由誫動の周期は

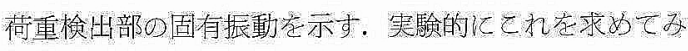
is.

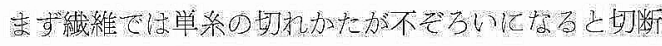
㭙の波形が不明裳记なる恐执がるので長さ約 $20 \mathrm{~cm}$, 直徍約 $0.12 \mathrm{~mm}$ の鉰線を用意して引張り諴験を行な5. とのよきの引張り速度は約 $7 \mathrm{~m} / \mathrm{s}$ 前後であ. 第16図に

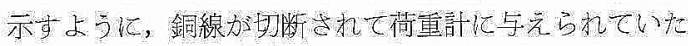

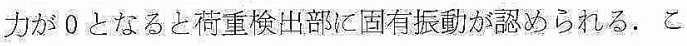

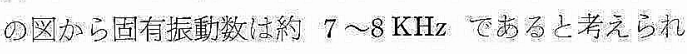
3.

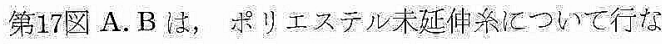
のた記錄でする。Aは，比較のたる，市販の固有振動数 


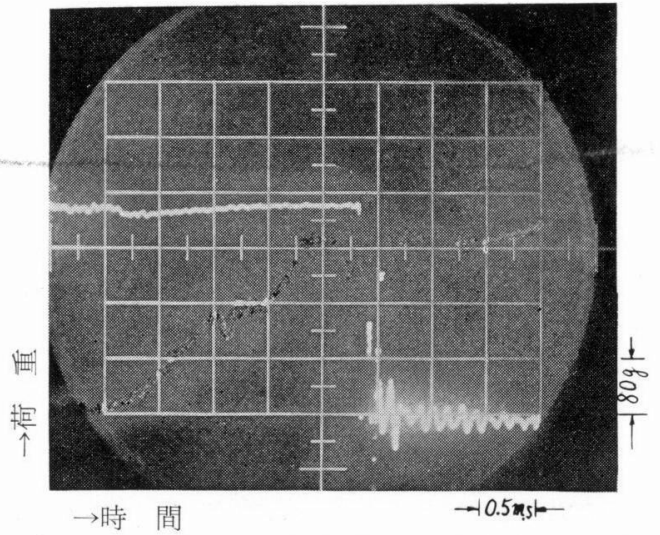

切断波形を測定するため銅線（長さ約 $20 \mathrm{~cm}$ ，直径 約 $0.12 \mathrm{~mm}$ ）を使用した．銅線が切れた後，荷重検 出部の固有振動が認められる.

第16図 荷重計の固有振動数の測定波形

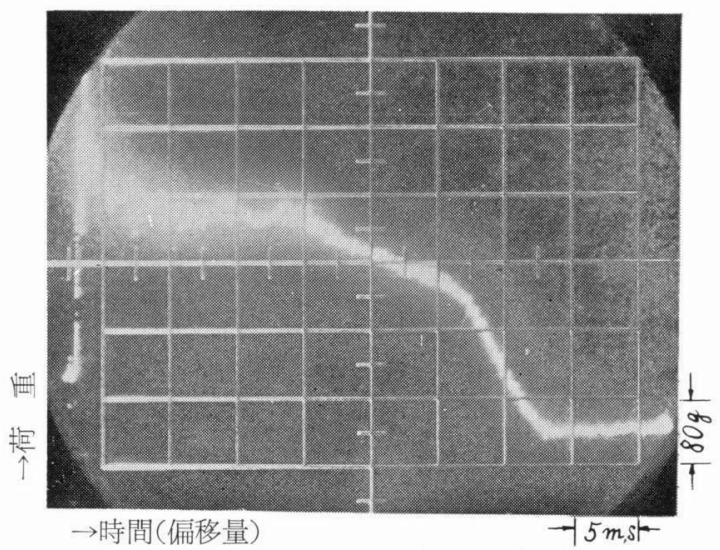

A ワイヤーストレインゲージ式荷重計

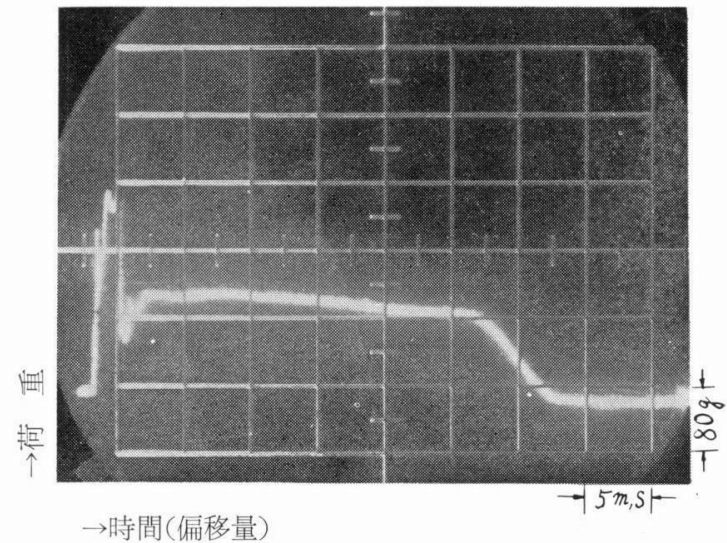

B 水晶発振子式荷重計

第17図 未延伸糸の高伸速变形時の荷伸曲線

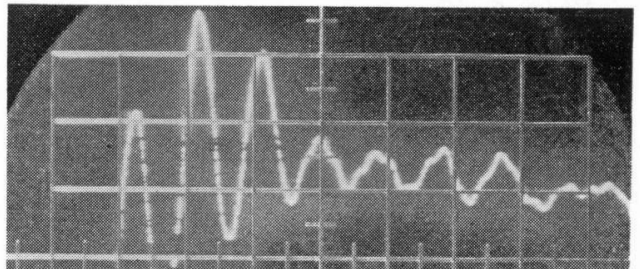

$\mathbb{\Psi}$

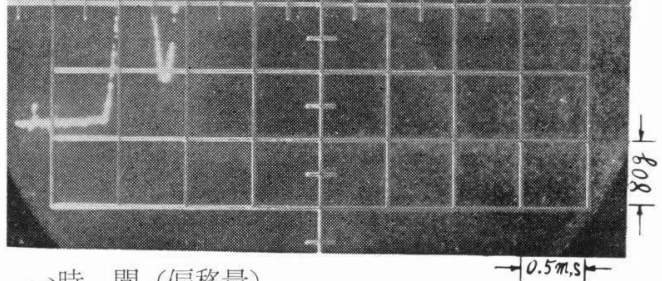

$\rightarrow$ 時 間 (偏移量)

A ワイヤーストレインゲージ式荷重計

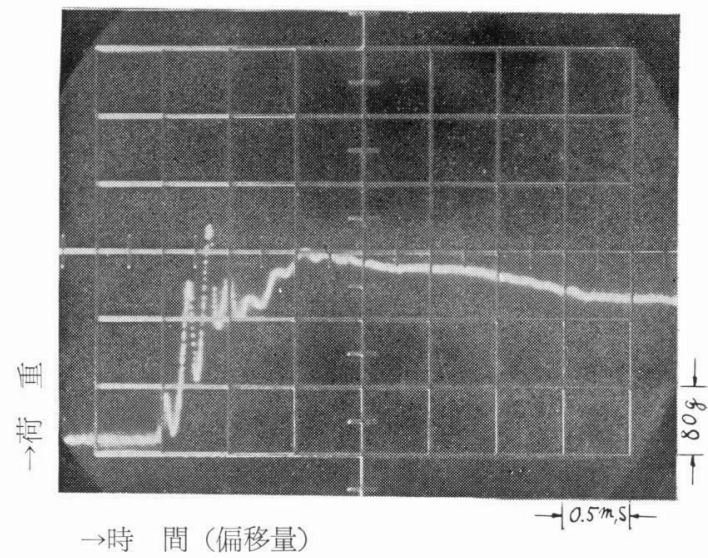

B 水晶発振子式荷重計

第18図 未延伸系の高速変形時の初期応力 


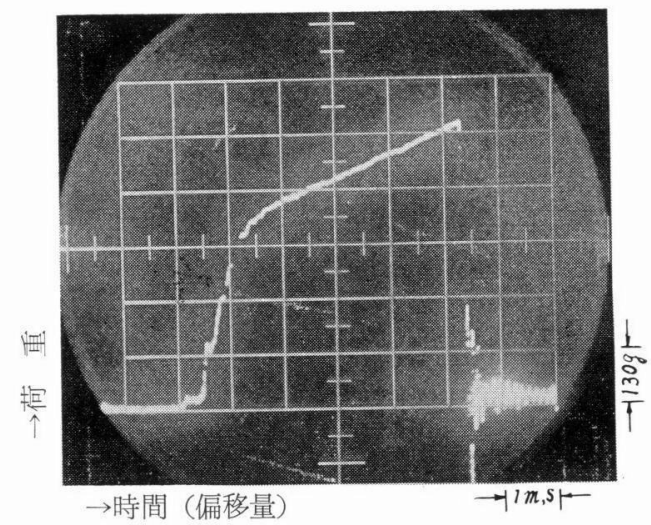

第19図 ポリエステル禾高速変形特性

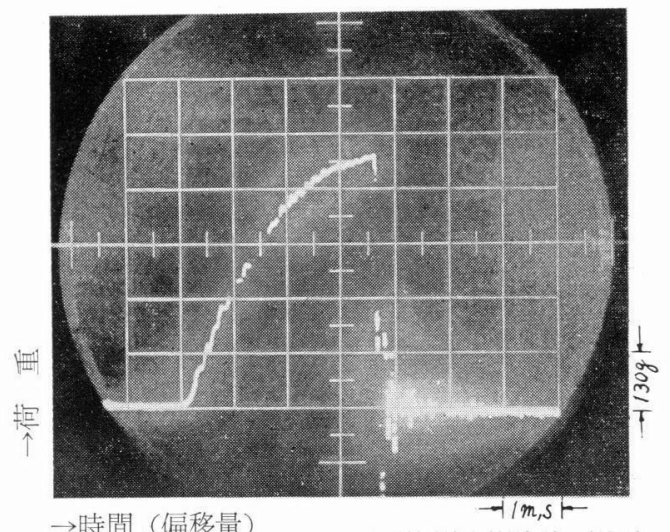

第20网 伸張絹ミシン采の高速変形特性

第19図は，水晶発振子を用いた場合のポリエステルミ シン杀 (市販品)，第20四は，絹ミシン糸（市販品）の 切䉼までの高速引張り特性である。これらの場合いずれ 屯試料長 $22 \mathrm{~cm}$, 弓張り速度約 $10 \mathrm{~m} / \mathrm{sec}$, 縦軸 $130 \mathrm{~g} / \mathrm{Div}$, 横軸 $1 \mathrm{~ms} /$ Div のものを示す.

以上に示すように, 水晶発振子の周波数変化から, 乙 れに与えられた荷重を求める方法では，静荷重はもちろ ん約 $10 \mathrm{~m} / \mathrm{s}$ の速さの引張り速度での荷重一伸長曲線も 測定することができた。しかし，高い周波数領域におい

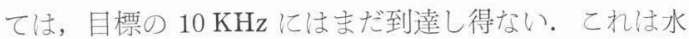

晶発振子の素子に荷重を賦荷する機構になお検討不十分 の点が残されているためではないかと考えられらる.

本研究は荷重計として水晶発振子を使用し, その発振 周波数の偏移が荷重に比例する原理を利用したものであ る.すなわち，発振子にある力向の力を与えると，それ に応じた周波数偏移を生じ，それは容易に出力として取 出すととができて，しかむこの取出し得る出力は，D.C 〜数 $\mathrm{KHz}$ にもおよぶ広带域にわたるとと，温度ドリフ 卜が 0 であること, などの本質的な特徴を利用して, 引 張り試験用荷重計の試作を試夕た.

最後に, 本研究に対し, 水晶発振子の製作上回路設計 を担当していただいた東洋通信機株水晶部，情報制御技 術部の諸氏, また, 本研究を発表するにあたり種々ご便宜 を与えられた当研究所, 椿茂雄所長に感謝いたします。

この報告は昭和 43 年度, 日本繊維機械学会第21回年次 大会で発表したあのである.

\section{文献}

1) K. B. O'neil ; M.F. Dague and J. E. Kimmel ; "High Speed Tensile Testing of Tire Textiles” (1967)

2) E. W. Lothrop JR ; "Impact Resistance of Automobile Tires"Ibid P.5 3 70

3）上野弥, 石川稔; “薄し高分子フィルムのための高速引 張り試験機の試作”材料, 14, No.139 P.23 27 (1965)

4) H. Grimminger ; "Basic Problems involved in the testing materials under destructive ultimate load at high strain rate" Applied polymer Symposia, High Speed Testing. V (1965)

5)五十風伊勢美；“半導体ひず計，扔よびをの応用”機械 学会㰻, 65, No.527(1962)

6）五十風伊勢美; “半導体ひずみ計について”計量管理, 14, No.5, P. $2 \sim 8$

7）五十風伊勢美；“ひずみ測定用半導体トランス シュー サー・計測之制御，5，No.2，P17〜26，（1966）

8) E.A. Gerber ; "Precision frequency. Control for guided missile" I. R.E. National Convention Record, Pt. 1, P. $90 \sim 98(1957)$

9) E. A. Gerber ; "Reduction of frequency temperature shift of piezoeletctric crystals by application of temperature dependent pressure" Pror, I. R.E. 48, P.244 $\sim 245(1960)$ 